\title{
Commentary
}

\section{Moving Upstream and Going Local: The Responsibility to Protect Ten Years Later}

\author{
Bridget Moix \\ School for Conflict Analysis and Resolution, George Mason University, Arlington, VA 22201, USA; \\ E-Mail: bmoix@masonlive.gmu.edu
}

Submitted: 2 May 2015 | Accepted: 7 May 2015 | Published: 27 October 2015

\begin{abstract}
Ten years ago the international community pledged to protect civilians from genocide, ethnic cleansing, war crimes, and crimes against humanity by endorsing the responsibility to protect (R2P) doctrine. Yet today, horrific violence against civilians continues in places like Syria, Iraq, and South Sudan. This article examines some of the progress and gaps in the international community's efforts to better protect civilians against mass violence over the past decade. It proposes two emerging directions for advancing the R2P agenda in the coming years: 1) greater focus on upstream prevention, and 2) increased support for locally-led peacebuilding and prevention actors and capacities.
\end{abstract}

\section{Keywords}

atrocity prevention; civilian protection; genocide; genocide prevention; mass atrocities; responsibility to protect; R2P

\section{Issue}

This commentary is part of the special issue "Mass Atrocity Prevention", edited by Professor Karen E. Smith (London School of Economics and Political Science, UK).

(C) 2015 by the author; licensee Cogitatio (Lisbon, Portugal). This article is licensed under a Creative Commons Attribution 4.0 International License (CC BY).

Ten years ago, the international community pledged to protect civilians from genocide, ethnic cleansing, war crimes, and crimes against humanity by endorsing the responsibility to protect (R2P) doctrine at the 2005 World Summit. Ten years later, horrific violence against civilians has now devastated tens of thousands of lives in places like Syria, Iraq, and South Sudan, with potential new waves of killing feared in countries like Burundi and Myanmar. Have we, as a global community, made any progress in making good on the now 70-year commitment of "never again", or has R2P been just another unfulfilled promise by international leaders?

The answer is a bit of both. Since the signing of the 2005 World Summit Document that committed global leaders to the three pillars of R2P, important progress has been made at the normative, policy, and practical levels. R2P laid out three pillars of responsibility, and some progress on each can be seen. These include: 1 ) primary responsibility of states to prevent and protect their own people, 2) responsibility of the international community to support states in implementing that commitment, 3) and responsibility of the international community to intervene under UN authorization if prevention fails.

Normatively, R2P expanded the narrow focus on genocide, and the definitional debates that often obstructed effective action to prevent it, to require action against a broader set of international crimes against civilians. While the inclusion of ethnic cleansing, war crimes, and crimes against civilians marked an important step in moving the international community beyond paralyzing debates to prove genocidal intent before acting and breaking out of the numbers game of measuring human suffering, the normative frame for R2P has expanded even further first to encompass a general narrative of "mass atrocities" and in more recent years "atrocity prevention" as a rising normative frame around which policymaking and practical efforts are now developing. While defining what constitutes "atrocities" or "atrocity prevention" and how it differs from broader violent conflict prevention may create new definitional debates, moving beyond R2P's original four 
crimes may be an important evolution to help the international community shift focus further "upstream" in its efforts to avert deliberate violence against civilians.

The most critical normative shift since R2P's adoption has, in fact, been the move away from a dominant focus on intervention after atrocities unfold-when the international community's tools are more limited and the consequences of spiraling violence much greaterto a much more serious focus on prevention before the killing begins. Although debates over military intervention can still consume the attention of policymakers and the press, dedicated work by a growing number of academics, policymakers, practitioners, civil society groups and local communities to improve capacities for early warning and preventive action are slowly but steadily gaining ground. Looking forward to the next ten years of international efforts to make good on the promise of $R 2 P$, continuing this shift in focus and resource investment toward earlier prevention will be critical.

At the policy and structural level, important steps have been taken that offer some hope. The United Nations, along with regional multilateral organizations in Latin America, Africa, and Asia, have created offices, dedicated positions, and governmental networks for early warning and response of genocide. These networks are made up of a growing number of government officials being trained (often by nongovernmental organizations) in genocide and atrocity prevention and developing relationships across regions that can foster information-sharing and analysis, complementary policy development, and practical action among decision-makers responsible for prevention and response within countries and regions at greatest risk. R2P's primary focus not on external intervention but rather state responsibility for protecting populations has been one of the most important contributions of the norm, and a growing number of national governments have identified "focal points" on genocide and atrocity prevention and put into place new policies and structures for preventing and responding to mass atrocities. In establishing specific genocide prevention mechanisms within the International Conference of the Great Lakes Region's, leaders in the region made a commitment to owning the problem of mass violence in their countries with the vision of moving from a "genocide-prone" reality to a "genocide-free" future. External powers are also creating internal structures to try to strengthen their capacities as well. The Obama Administration's commitment to make mass atrocity prevention a "core national security interest and core moral responsibility of the United States", as outlined in Presidential Study Directive 10 in 2011, and subsequent establishment of the interagency Atrocities Prevention Board within the White House's National Security Council, is one example.

In practice, the R2P doctrine has also been employed in a number of situations to try to prevent or de-escalate atrocity crises. In response to the postelection crisis in Kenya in 2007/2008 that killed some 1,300 people and displaced tens of thousands, the international community invoked the responsibility to protect as part of a coordinated diplomatic messaging and mediation effort to compel the country's leaders to restrain the violence and reach a negotiated settlement. A multi-year preventive effort followed within Kenya and by many in the international community to avert another electoral crisis five years later. In the Central African Republic, as fears of genocidal violence rose in 2013 , the international community mobilized a significant response to what has been one of the most neglected countries in the world. In this case, while the response still came too late to save thousands of lives and may be difficult to sustain for the time it will take to ensure a path out of decades of cycles of violence, governance and development crises, the role of specific atrocity prevention mechanisms like the US Atrocities Prevention Board and United Nations-authorized peacekeepers did make a difference. In Libya in 2011, a NATO military intervention was mobilized to respond to what was seen by some as a pending slaughter of thousands of civilians. Unfortunately, in that case, the results are much less encouraging, with continued chaos, hundreds of armed militias, and the rise of new extremist elements targeting civilians. Now, as Burundi teeters on the edge of a potential atrocity crisis, the international community is again mobilizing to apply as many tools as possible-high-level diplomatic engagement, individual sanctions, UN Security Council action, human rights monitoring, peace messaging, community radio, humanitarian aid, and other support to civil society. As Burundian police cracked down on civil society protests in late April, the Burundian military played a remarkable role to directly protect civilians in the streets, a testament to the potential for civilian protection norms to take hold among key individuals and institutions even while state leaders are perpetuating abuses.

What are the lessons we should learn from the past ten years and where is the R2P landscape headed? While we should affirm and continue supporting the normative, policy, and practical steps that have been taken over the past decade, far too many lives continue to be lost and destroyed to become complacent. The failures of the global community in recent years demand renewed commitment and concerted work to make R2P a reality, not just rhetoric. In Darfur, ten years after a massive international mobilization by governments and civil society, little is being done while civilians continue to be killed and raped in large numbers, having become the forgotten genocide of our time. In Syria, despite significant international attention, the violence continues unabated, including direct targeting of communities with barrel bombs and chemical weapons, while a regional crisis of extremist vio- 
lence, ungoverned space, and humanitarian catastrophe unfolds. These and other cases underline the reality of how complex and difficult implementing R2P still is, and how much more still needs to be done.

Two emerging directions can help ensure the next ten years build on the gains thus far and improve our approaches and tools for preventing violence against civilians in future. First, the shift toward further "upstream" prevention must continue. Rhetorically, we have come a long way since just ten years ago in focusing on the need to "stop the killing before it begins" through better early warning and analysis, preventive diplomacy, and dedicated programs and funding before mass violence ensues. But the persistent challenges of mobilizing political will and resources without the headlines of a crisis, and proving what works when things do not happen, remain. We need to build a stronger empirical evidence base on prevention through creative research that tackles the counterfactual challenge rather than succumbing to it. And we need focused education, advocacy, and engagement with policymakers to demonstrate convincingly the reality that prevention is more effective and less costly than responding after violence is underway. Moving upstream can also avoid the nasty problem of military interventions that seem like the only option available, but often introduce an additional danger into already highly complex and dangerous crises, fueling conflict and suffering in the long run.

Second is the growing focus on strengthening local capacities-national capacities but particularly local civil society-to be more resilient against the risks of atrocities and mass violence. A growing body of research is documenting the ways in which communities act, often on their own accord and sometimes in partnership with national and international groups, to resist, rescue, and protect against attacks on civilians. This includes, for example, local peacebuilding, selfprotection strategies, nonviolent action, community- based early warning and response systems, human rights documentation, peace messaging, and promoting tolerance, dialogue, and positive economic interdependence across conflict groups. Effective prevention requires shoring up the "front lines" where violence against civilians occurs. These front lines are local communities. Recognizing their agency (not just victimhood) and primary role in helping the global community implement R2P is a necessary and critical shift for the coming years. Most attention and resources still go toward Pillar I and Pillar III, while the greatest promise lies in Pillar II, which must include supporting civil society, not just state capacities for protection and prevention. Investing more resources and support to local civil society so they can identify, design and develop the mechanisms they need in order to build longterm peacebuilding and prevention capacities, understand and act on risks in their earliest stages, hold their governments accountable for protecting their populations, and engage external support from the international community when needed, should be priority number one in the years ahead.

Preventing mass violence against civilians has become, rightly, a growing global cause, but it also remains, tragically, a deeply local reality for far too many people. As such it requires both global and local solutions.

\section{Acknowledgments}

The author wishes to thank all those working against the odds in situations of conflict to help prevent violence and atrocities, and the many individuals who have worked to advance a local and global agenda for peacebuilding and prevention over the past decade.

\section{Conflict of Interests}

The author declares no conflict of interests.

\section{About the Author}

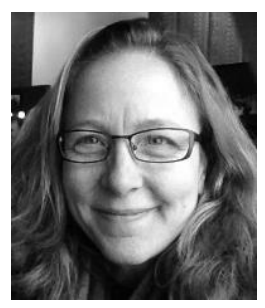

\section{Bridget Moix}

Bridget Moix has worked for 20 years on issues of international peace and conflict. She is currently a Senior Fellow with the Genocide Prevention Program at George Mason University's School for Conflict Analysis and Resolution, where she is also a PhD candidate. Bridget also serves as US Senior Representative for Peace Direct, a UK-based organization that works to support local peacebuilders in conflict situations around the world. She recently worked for two years as an Atrocity Prevention Fellow with the US Agency for International Development. 